\title{
What is Meant by Fellowship and What are its Types?
}

\author{
Farhan Raza Khan
}

BDS, MS, MCPS, FCPS

The term 'fellowship' is fairly common among medical and dental graduates especially those aspiring to become subject specialists. However, there are so many meanings and construct of this term that not only patients but even students get confused. The following description explains what fellowship is all about and what its types are. Actually, fellowship has eight different meanings.

KEYWORDS: Fellowship; award; examination; diploma

HOW TO CITE: Khan FR. What is Meant by Fellowship and What are its Types?. J Pak Dent Assoc 2021;30(2):130-131.

DOI: https://doi.org/10.25301/JPDA.302.130

Received: 12 May 2020, Accepted: 25 February 2021

$\mathrm{T}$ he term 'fellowship' is fairly common among medical and dental graduates especially those aspiring to become subject specialists. However, there are so many meanings and construct of this term that not only patients but even students get confused. The following description explains what fellowship is all about and what its types are; Actually, fellowship has following meanings:-

\section{FELLOWSHIP AS A HIGHER CLINICAL DIPLOMA}

Traditionally, fellowship is the name of the higher clinical examination administered by the royal colleges in the UK (London, Edinburgh \& Glasgow) and Ireland (Dublin). These colleges (their nominated examiners in the specialist faculty) confer the higher diplomas to the candidates who have completed their structured training at approved posts and have successfully pass the high-end written and oral examination as a terminal qualification and thus admitted into the college fellowship. ${ }^{1}$ Diplomas such as FRCS, FRCSI, FRCP, FRCA, FRCPath, FDSRCS or FFDRCSI are some examples. Although specialty FDS is the exit level examination in UK and Ireland, recent changes in the nomenclature in UK, have made the specialty membership examination in dental disciplines as the exit level examination. In Pakistan, the College of Physicians and Surgeons (CPSP) follows the British model and confers FCPS diploma to the candidates who fulfill all the requirements including residency training, workshops, logbook, written examination, OSCE and oral examination plus approval of a dissertation or two papers published in indexed journals (Index Medicus), as first or second author, in lieu of the dissertation. ${ }^{2}$ The protocols of the papers must be approved by the Research training and monitoring cell at the CPSP before initiation of the study.

Associate Professor, Operative Dentistry, Chief of Dental Services, Aga Khan University Karachi, Pakistan.

Corresponding author: “Dr. Farhan Raza Khan” < farhan.raza@aku.edu >
Other reputable colleges such as The College of Physicians \& Surgeons in Bangladesh, Royal College in Canada and, The Royal Australasian College of Dental Surgery award their respective fellowship diploma on similar grounds as done in Ireland.

\section{FELLOWSHIP AS A HIGHER DIPLOMA IN EDUCATION}

Some institutions confer fellowship upon completion of higher training or achieving excellence in education. These include the well-known FAIMER (Foundation for the Advancement of International Medical Education \& Research) offered by ECFMG in the USA. ${ }^{3}$ Similarly, a fellowship pertaining Fellowship in Dental Education is conferred by the faculty of dental trainers at the Royal College of Surgeons abbreviated as FDT RCSed. ${ }^{4}$

\section{HONORARY FELLOWSHIP AS A TOKEN OF APPRECIATION}

On certain exceptional grounds, the terms of reference of the royal colleges (or even CPSP) allow them to award their fellowship diploma without examination to any eminent senior clinician/politician/artist or social worker as a token of recognition of service in the public domain. It's mandatory to write the term "honorary" with such diplomas. ${ }^{5}$ it's interesting to note that there is no policy available to the public as to who will be entitled to the honorary fellowships. Mostly, it's the discretion of the council and the president of the college to confer this honor to the guest at the convocation.

\section{FELLOWSHIP AS AN ADMISSION TO A REPUTABLE SCIENTIFIC SOCIETY/ ACADEMY}

The Royal Society (UK) fellowship falls into this category. There is no examination involved in this 
fellowship. Annual election or nomination of very few select individuals belonging to medicine, natural science or mathematics are given this fellowship honor on their outstanding merit and contributions to the advancement of science.$^{6}$ These fellows are the most eminent scientists and researchers in their respective disciplines. Names such as Isaac Newton, Charles Darwin, Albert Einstein, Francis Crick and Stephan Hawking are some examples. So far, only a few Pakistanis have received this fellowship. These include well-respected names such as Dr Salimuzzaman Siddiqui, Dr Abdul Salam, Dr Muhammad Akhter, Dr Atta ur Rehman and Dr Zulfiqar Bhutta. The American equivalent of such award is called the Membership of the National Academy of Sciences.

\section{FELLOWSHIP AS A MISNOMER FOR PROFESSIONAL MEMBERSHIP}

A number of professional societies, associations and academies use the term fellowship in lieu of membership for their members ${ }^{7}$. These are professionals who have demonstrated affiliation with the professional body for the specified time period with some additional requirements of submitting clinical cases/ demonstrating skills and knowledge. However, residency training is not an essential requirement for such a fellowship. Similarly, these fellowships don't account for academic appointments or promotion on professorial rank. Outstanding contribution to the discipline of practice is not a requirement. Examples are fellowships in the Academy of Maxillofacial Prosthetics, Academy of Implant Dentistry or American Association of Oral Maxillofacial Surgeons etc.

\section{FELLOWSHIP AS TUITION WAIVER}

In North America, (USA and Canadian) universities use the term fellowship synonymous with the scholarship. ${ }^{8}$ This is especially true for graduate programs where students who get a tuition fee waiver or scholarship or any freeship / bursary are called as students on fellowship. Usually, these students are given this waiver on their merit/ past academic performance.

\section{FELLOWSHIP AS POST-RESIDENCY CLINICAL TRAINING PROGRAM}

Hospitals in USA frequently use the term fellowship training for those post graduate trainees who have already done their primary clinical residency training and now are admitted into the sub-specialty/ super specialty training. ${ }^{9}$ For example, a fresh Urology graduate might want to do a fellowship in prostate cancer or a nephrologist would pursue fellowship training in renal transplant unit. In dentistry, post-residency fellowships are presently non-existent but there will be a time in future where some Prosthodontists would do training in Maxillofacial Prosthodontics, Operative/Endodontists in Microsurgical Endodontics, Orthodontist in Lingual Orthodontics and Oral Surgeons would pursue fellowship in Orthognatic Surgery etc.

\section{FELLOWSHIP AS POST-DOCTORAL RESEARCH TRAINING PROGRAM}

The formal research training after acquiring a Ph.D. is called post-doctoral fellowship. ${ }^{10}$ Most of these post-doctoral fellowships are paid by the host institution. An example would be one offered by National Institute of Health (NIH) that provides funding for postdoc fellowships. During this period, a post doc fellow advances his/ her research work, refines research questions and learn new methods and publishes in journal to gradually become an independent researcher.

\section{CONFLICT OF INTEREST}

None to declare

\section{REFERENCES}

1- https://www.rcsed.ac.uk/the-college/about-us

2- https://www.cpsp.edu.pk/fcps.php

3- https://www.faimer.org/about.html

4- https://fdt.rcsed.ac.uk/how-to-join/membership-categories

5- https://www.rcsed.ac.uk/news-public-affairs/news/2014/ april/world-renowned-head-and-neck-cancer-surgeon-to-receivehonour-from-rcsed

6- https://royalsociety.org/fellows/

7- https://www.aaoms.org/become-a-member/applyonline/fellowmember

8- https://grad.illinois.edu/gradhandbook/2/chapter7/tuitionwaivers\#fellow

9- https://college.mayo.edu/academics/residencies-andfellowships/maxillofacial-prosthetics-and-dental-oncology-fellowshipminnesota/

10- https://www.humboldt-foundation.de/web/humboldt-fellowshippostdoc.html 